\title{
THE RELATIONSHIP OF THE BLOOD GLUCOSE TO THE CONCEN- TRATION OF LACTOSE IN THE MILK OF LACTATING DIABETIC WOMEN
}

\author{
By EDWARD TOLSTOI \\ (From the New York Hospital and the Department of Medicine, Cornell University Medical \\ College, New York)
}

(Received for publication July 9, 1935)

The mammary gland has a specific function, namely the secretion of milk. In the process of elaborating this unique fluid, the gland actually manufactures quantities of protein, fat and carbohydrate, as casein, milk fat, and lactose are the specific substances produced. Since these constituents are not found in blood normally, they are assumed to be synthesized by the mammary gland from the glucose, amino acids and the phospholipine brought to it by the blood (1). My interest in the problem is limited to the carbohydrate metabolism, and this paper deals with the presentation of such data. If, as is generally accepted, the glucose of the blood is the raw material from which lactose is made, the question arises whether there is a quantitative relationship between the two. Can the concentration of the lactose be increased or diminished by altering the glucose concentration of the blood?

There is considerable evidence obtained from animal experiments that the glucose of the blood is the precursor of the lactose of the milk. There are also on record perfusion experiments on excised mammary tissue of animals which lend support to this view. In addition, there are data derived from experiments which go a step further. These experiments demonstrate that not only is the lactose of the milk synthesized from the blood glucose, but that there is a quantitative relationship between them as regards the concentration and the total quantity produced.

In 1884 Bert (2) removed the mammary glands of goats. These animals were then bred and after parturition a reducing substance was found in the urine. The urine of the control animals did not contain this reducing substance. From such findings Bert made the following deductions : First, that a hyperglycemic state occurs after parturition to furnish the lactating gland with more material for the production of lactose, and second, that since the mammary gland is not present to utilize the sugar a mellituria develops. The nature of this reducing substance found in the urines of such experimental animals was not known until 1909 when Porcher (3) confirmed Bert's work and identified the reducing substance as glucose. Both of these investigators stated that the postpartum glycosuria of their experimental animals was of short duration. These experiments furnished indirect evidence that the body prepares itself for the process of lactation by an elevation of the blood sugar and that it is the glucose of the blood which is used for the manufacture of the lactose. There are other animal experiments which have a bearing on the problem, and which more definitely establish such a relationship. Kaufmann and Magne (4) working with cows, took samples of blood from the mammary vein and also the jugular vein for glucose studies. The specimen from the jugular vein was assumed to be comparable in composition to that of the mammary artery. In lactating animals the blood going to the mammary gland as represented by the jugular blood had eighteen per cent more glucose than the blood leaving it, while in non-lactating animals the sugar concentration of the blood showed no such difference. Cary (5), cited by Meigs, confirmed these results. This investigator was extremely careful to obtain specimens simultaneously from the jugular and mammary veins by means of cannulae in each so that the time variable would be minimized.

The above experiments with living animals offer strong evidence that glucose is the precursor of the milk sugar. An additional clinical observation lends further support to this conclusion. It is recognized among dairy men that heavy milking cows develop a condition known as milk fever and that this condition may develop acutely during the process of milking. The clinical picture and 
the laboratory evidence point to a hypoglycemic reaction. To remedy this condition measures are directed towards elevating the blood sugar. This has been done by either injecting glucose into the blood stream or by stopping the production of milk by inflating the udder with air. It has been inferred that the latter procedure is effective because by terminating lactation it enabled the organism to retain its glucose and thus maintain the concentration of this substance at a normal level in the blood and tissues.

Foa (6), working with excised mammary glands of sheep, demonstrated that not only is the blood glucose a precursor of the milk lactose, but that a quantitative relationship exists between them. He perfused excised glands kept in Ringer's solution, and he could definitely increase the lactose content of the milk produced by increasing the concentration of glucose in the perfusing fluid. $\mathrm{He}$ also noted that blood and Ringer's solution as the perfusing mixture caused a secretion of milk; that Ringer's solution and dextrose alone caused the secretion of a watery fluid containing lactose; that the glucose content of the perfusing fluid diminished as the breast continued to produce lactose, and furthermore that Ringer's solution alone or with galactose did not result in the formation of lactose. These experiments offer conclusive evidence that the excised mammary glands convert glucose to lactose, and that the more glucose in the perfusing fluid, the greater was the concentration of the lactose produced.

The application of such results to living animals might meet with objections because conditions are much altered, and furthermore the nervous control of the secretory mechanism is removed. It would, therefore, be desirable to produce a hyperglycemia in the living animal and note the resulting concentration of lactose from such a procedure. In the normal living animal Meigs (7) states that the concentration of milk sugar is most constant and is in no way affected by variations in the diet. This statement is not an unexpected finding as it is difficult to produce abnormal elevations in the glucose concentration in the blood of normal animals by increasing the carbohydrate content of the diet. Given, however, a lactating diabetic patient whose blood sugar can be elevated to markedly abnormal levels, or whose blood glucose can also be dropped below the normal concentration, what effect will such procedure have on the lactose concentration of the milk?

In an attempt to answer this question five diabetic lactating mothers were employed. All were about two weeks postpartum. The severity of the diabetes varied but all were controlled without much difficulty while in the hospital. The control of their diabetes was somewhat more diffcult while they were cared for in the outpatient department during the antenatal period, but at no time were they serious problems. One of the patients was managed by diet only. The other three required insulin to maintain the urine free from sugar. The maximum amount used in any case was 30 units, the minimum was 15 units. The youngest patient was 30 and the oldest 40 years old. The blood sugar was elevated by the administration of glucose by mouth. All of the patients were given 100 grams of glucose, before breakfast. Blood was drawn before and at $1 / 2$, 1,2 , and 3 hours following the ingestion of the glucose. The blood specimens were obtained from the antecubital vein and discharged into tubes containing about $2 \mathrm{mgm}$. of potassium oxalate for each cubic centimeter of blood. The breast milk was obtained at about the same time intervals by means of a breast pump. The first 2 or 3 cc. of milk collected at the times specified were discarded. The remainder was used for analysis.

In four of the patients, the blood glucose and lactose of the breast milk were studied following the administration of insulin. These patients reported before breakfast at which time a blood and milk sample were obtained. Following this, insulin was administered subcutaneously. The amount given varied in each case and depended on the height of fasting blood sugar. The exact amounts injected are shown in Table II. About $31 / 2$ hours later, when symptoms of nervousness, hunger and a feeling of heat became apparent, blood and milk samples were again obtained. It was felt that the clinical manifestations mentioned were early symptoms of a hypoglycemia., During this experimental period none of the patients received any food or fluids.

The glucose of the blood was determined by the colorimetric method of Benedict (8). The 
lactose of the milk was done by the procedure of Owen and Gregg (9).

From Tables I and II it is obvious that the concentration of the milk sugar in the human lactating diabetic is constant, and is not influenced by the quantity of blood glucose circulating at a given time. This fact is not in accord with Foa's conclusions, but the difference might be easily accounted for by the difference in experimental conditions. The above data are based on results obtained on living diabetic women, while Foa's conclusions were drawn from results of perfusion experiments in which excised breasts of nondiabetic animals were used.

The validity of the foregoing conclusions might also be questioned as far as their applicability to normal non-diabetic women is concerned. The carbohydrate metabolism in the latter is normal, and it may therefore be argued that in healthy non-diabetic women, the lactating breast may vary its lactose concentration with changes in the glu-

TABLE I

Showing the constancy of the milk lactose after marked blood sugar elevations

\begin{tabular}{|c|c|c|c|c|c|}
\hline & \multirow{2}{*}{$\begin{array}{c}\text { Fast- } \\
\text { ing }\end{array}$} & \multicolumn{4}{|c|}{$\begin{array}{l}\text { Following the ingestion of } \\
100 \text { grams of glucose }\end{array}$} \\
\hline & & hour & 1 hour & 2 hours & 3 hours \\
\hline $\begin{array}{l}\text { Patient J. G. } \\
\text { Blood sugar, mgm. per } \\
100 \text { cc............. } \\
\text { Lactose of milk, grams } \\
\quad \text { per } 100 \text { cc......... }\end{array}$ & $\begin{array}{r}221 \\
8.0\end{array}$ & $\begin{array}{r}313 \\
7.5\end{array}$ & $\begin{array}{r}341 \\
8.0\end{array}$ & $\begin{array}{r}384 \\
8.2\end{array}$ & $\begin{array}{r}358 \\
7.8\end{array}$ \\
\hline $\begin{array}{l}\text { Patient R. S. } \\
\text { Blood sugar, mgm. per } \\
100 \text { cc............. } \\
\text { Lactose of milk, grams } \\
\text { per } 100 \text { cc. . . . . . . }\end{array}$ & $\begin{array}{r}150 \\
7.4\end{array}$ & $\begin{array}{r}180 \\
7.7\end{array}$ & $\begin{array}{r}340 \\
7.6\end{array}$ & $\begin{array}{r}380 \\
7.6\end{array}$ & $\begin{array}{r}450 \\
7.5\end{array}$ \\
\hline $\begin{array}{l}\text { Patient E. K. } \\
\text { Blood sugar, mgm. per } \\
100 \text { cc............. } \\
\text { Lactose of milk, grams } \\
\text { per } 100 \text { cc......... }\end{array}$ & $\begin{array}{r}102 \\
6.9\end{array}$ & $\begin{array}{r}206 \\
6.2\end{array}$ & $\begin{array}{r}213 \\
5.6\end{array}$ & $\begin{array}{r}238 \\
5.8\end{array}$ & $\begin{array}{r}189 \\
5.0\end{array}$ \\
\hline $\begin{array}{l}\text { Patient M. M. } \\
\text { Blood sugar, mgm. per } \\
100 \text { cc............. } \\
\text { Lactose of milk, grams } \\
\text { per } 100 \text { cc......... }\end{array}$ & $\begin{array}{r}109 \\
7.3\end{array}$ & $\begin{array}{r}172 \\
6.1\end{array}$ & $\begin{array}{r}293 \\
7.0\end{array}$ & $\begin{array}{r}299 \\
6.9\end{array}$ & $\begin{array}{r}225 \\
6.7\end{array}$ \\
\hline $\begin{array}{l}\text { Patient } \mathrm{H} . \\
\text { Blood sugar, mgm. per } \\
100 \text { cc............ } \\
\text { Lactose of milk, grams } \\
\text { per } 100 \mathrm{cc........}\end{array}$ & $\begin{array}{r}104 \\
5.3\end{array}$ & $\begin{array}{r}160 \\
5.2\end{array}$ & 244 & 290 & $\begin{array}{r}191 \\
5.4\end{array}$ \\
\hline
\end{tabular}

TABLE II

Showing the constancy of the milk lactose after marked lowering of the blood sugar

\begin{tabular}{|c|c|c|}
\hline & $\begin{array}{c}\text { Fast- } \\
\text { ing }\end{array}$ & \\
\hline $\begin{array}{l}\text { Patient J. G. } \\
\text { Blood sugar, mgm. per } \\
100 \text { cc............. } \\
\text { Lactose of milk, grams } \\
\text { per } 100 \text { cc........... }\end{array}$ & $\begin{array}{r}277 \\
7.9\end{array}$ & $\begin{array}{l}3 \frac{1}{2} \text { hours after } 30 \text { units of } \\
\text { insulin } \\
\begin{array}{c}85 \\
7.9\end{array}\end{array}$ \\
\hline $\begin{array}{l}\text { Patient } \mathrm{H} . \\
\text { Blood sugar, } m g m . \text { per } \\
100 \text { cc............ } \\
\text { Lactose of milk, grams } \\
\text { per } 100 \text { cc......... }\end{array}$ & $\begin{array}{r}147 \\
6.0\end{array}$ & $\begin{array}{l}\frac{31}{2} \text { hours after } 20 \text { units of } \\
\text { insulin } \\
52 \\
5.8\end{array}$ \\
\hline $\begin{array}{l}\text { Patient } \mathrm{R} . \\
\text { Blood sugar, mgm. per } \\
100 \text { cc........... } \\
\text { Lactose of milk, grams } \\
\quad \text { per } 100 \text { cc......... }\end{array}$ & $\begin{array}{r}119 \\
6.3\end{array}$ & $\begin{array}{c}\frac{3 \frac{1}{2} \text { hours after } 20 \text { units of }}{\text { insulin }} \\
\qquad 4 \\
6.5\end{array}$ \\
\hline $\begin{array}{l}\text { Patient } \mathrm{S} . \\
\quad \\
\text { Blood sugar, mgm.per } \\
100 \text { cc............ } \\
\text { Lactose of milk, grams } \\
\quad \text { per } 100 \text { cc......... }\end{array}$ & $\begin{array}{r}178 \\
7.2\end{array}$ & $\begin{array}{c}\begin{array}{c}3 \frac{1}{2} \text { hours after } 25 \text { units of } \\
\text { insulin }\end{array} \\
44 \\
6.9\end{array}$ \\
\hline
\end{tabular}

cose content of the blood. The results of the four experiments in which insulin was administered refute such objections.

It is now well established that in diabetes, insulin aids in the utilization of carbohydrates. In other words it converts, at least for the period of its activity, a diabetic into a non-diabetic. That being the case the four diabetic women, to whom insulin was given and whose blood sugar and milk lactose were studied, were for the period of the insulin activity normal, as regards their ability to utilize glucose. The sharp drop in the blood glucose following the administration of insulin support this inference. Yet, in spite of this pronounced fall in the blood glucose, three hours after the patient had received insulin, the concentration of the milk sugar was not lowered. As a matter of fact, it remained remarkably constant even though there was progressively less circulating glucose from which lactose was synthesized. This observation thus reveals that the lactating diabetic woman secretes milk, the lactose content of which does not differ from the normal, and furthermore, the concentration of the lactose is not influenced by variations in the blood glucose. 
SUMMARY AND CONCLUSIONS

Five diabetic, lactating women were studied to determine whether a quantitative relationship exists between the concentration of glucose in the blood and of lactose in the milk. The blood sugar was elevated by means of glucose ingestion and lowered by varying doses of insulin. It was found in every instance that the concentration of lactose in the breast milk remained remarkably constant in spite of very marked elevations or depressions of the blood glucose concentration.

My thanks are due to Dr. Henricus J. Stander of the Department of Obstetrics and Gynecology for the opportunity of studying the cases. Mr. J. Francis Cadden performed the milk analyses. This is gratefully acknowledged.

\section{BIBLIOGRAPHY}

1. Wright, Samson, Applied Physiology. Oxford Medical Publications, London, 1928, 2nd ed., p. 175.

2. Bert, Paul, Sur L'origine du sucre de lait. Compt. rend. Acad. d. sc., 1884, 98, 775.

3. Porcher, Ch., L'origine de lactose. Arch. internat. de physiol., 1909, 8, 356.

4. Kaufmann, M., and Magne, H., Sur la consommation du glucose du sang par le tissu de la glande mammaire. Compt. rend. Acad. d. sc., 1906, 143, 779.

5. Cary. Cited by Meigs (7).

6. Foa, C. Cited by Meigs (7).

7. Meigs, E. B., Milk secretion as related to diet. Physiol. Rev., 1922, 2, 205.

8. Benedict, Stanley R., The estimation of sugar in blood and normal urine. J. Biol. Chem., 1926, 68, 759.

9. Owen, R. G., and Gregg, Roth, Determination of lactose in milk by colorimetric method. J. Lab. and Clin. Med., 1920, 6, 220. 